\title{
From private writing to public oration: The case of Puritan wills. Cognitive discourse analysis applied to the study of genre change
}

\section{Ulrich Bach}

\section{Prologue}

The last will made in 1566 by Henry Cockrofte, who was a fellow of Trinity College (Cambridge) and a Marian exile, contains 25 manuscript lines in the volume of registered copies of the Vice-Chancellor's Court. Only three and a half lines contain legacies proper of his worldly goods. The rest, after the opening formula that the testator is making his will, is devoted to religious considerations. It is not the fact that there are only few legacies but the length of the religious part which at a glance marks this will as different from the traditional, pre-Reformational will. What is the reason for this change, which can also be noted in the wills of his fellow Puritans?

We may readily answer this question by pointing out that the insertion of religious passages in these wills is not really surprising; after all, the testators were ardent Protestants, advocates of beginning Puritanism. Professing one's absolute belief in the certainty of salvation, quoting the Bible and praising the Lord for wordly goods are demonstrably all elements of the Puritan code of conduct which is known from other sources, ${ }^{1}$ and this fully explains their occurrence in these wills. But this answer does not satisfy the student of discourse who looks pragmatically for the recipients and the functions of a will. A will's natural recipient is the executor. It is his particular task of carrying out the testator's last instructions meticulously and to the best of his understanding which is met by the traditional will's characteristic structural feature - the simple itemization of the series of bequests. Religious catechizing, confessions and polemic discussions of controversial issues of faith are at best irrelevant if not interfering with this task. Doubtless we may assume that Puritan testators, too, had a genuine interest in providing for surviving dependants. To achieve this aim, however, clear comprehensibility and successful execution of the will are required. So the real problem lies in 
the pragmatic conflict between this aim and the Puritan change of the testament as exemplified by the will of Henry Cockcrofte. The general question of the reason of this change becomes the pragmatic one of "who is to benefit by it?"

\section{Introduction}

\subsection{Theoretical background}

It is my thesis that the Puritan changes of the will are in the interest of a public audience which is to be edified, catechized and convinced by a reading out of the will's religious parts. I want to prove this by showing that, and how, the linguistic changes meet the particular comprehensional requirements of this type of audience, in an oral situation of communication. In other words, I shall ask: "Does a listening comprehender benefit from the changes?" The more far-reaching implication of a positive answer is the discovery of a functional change of the genre of last will following the upheavals of Reformation thinking in England, a change that went unnoticed by diachronic linguistics.

The analysis of strategies of specific comprehension management in Puritan wills implies a cognitive approach. Before applying it to the linguistic phenomena under consideration I want to answer two preliminary questions of theoretical and historical interest respectively. First, what do I mean by "cognitive approach"? Second, what is the pragmatic background of will-making in the 16th century?

By "cognitive approach" I mean in an ad hoc way the analysis and explanation of linguistic phenomena with a view to describe their effects on comprehension and retention of the comprehender, using recent findings in cognitive discourse research. Put differently, this approach aims at a methodology for interpreting the occurrence of specific linguistic phenomena in historical discourse as part of a comprehension-guiding strategy. Let me illustrate this point by a brief example. The inclusion of a prayer expressing the absolute certainty of salvation in a will is a fact which can be accounted for by tracing its source to a Puritan doctrine of belief and also to Puritan readings of the Bible, ${ }^{2}$ that is, by comparing it with contemporary writings and ideas - what I would call a philological approach. But the same fact also represents an instance of the modification of the will's superstructure which has consequences for the comprehender. Now if from the cognitive point of view we find that the 
original unmodified superstructure complies with the particular task of the will's "natural" recipient in the typical situation of communication and thus recognizably fulfills a cognitive function, then the modification of that superstructure raises the problem of how it affects that function. In principle, then, I propose to make use of concepts and findings of discourse comprehension research as a means for identifying the function of particular linguistic phenomena and explaining their occurrence in a particular historical discourse.

Discourse comprehension research as a subfield of cognitive science has since its emergence in the early 1970s restricted itself to synchronic analyses of present-day occurrences of discourse, as any look at journals such as Text and Discourse Processes, or series like Advances in Discourse Processes will quickly show. One of the rare examples of historical pragmatics employing a mentalistic point of view is, within the field of French Studies, the work of Schlieben-Lange (1983), who analyses traditions of talking and concentrates on the cross-relationship between the French Revolution and contemporary linguistic consciousness. From the point of view of the historian, Spufford (1974: 320 - 334) has explored the mentality of 16 th and 17 th century Cambridgeshire villagers, using their last wills as evidence. Discourse-level analysis of legal texts including last wills "has hardly begun" (Danet 1985: 285); it is non-existent with regard to historical last wills. The little research there is, following Danet (1985) - e.g., Fisher - Todd (eds. 1986) - does not cover the diachronic perspective, neither do so the short studies of wills by Finegan (1982) and Kurzon (1984, 1986: 39-47).

Doubtless the reason for this obvious reluctance towards a diachronic application of pragmatic and cognitive discourse analysis lies in the fact that any attempt to reconstruct historical instances of discourse comprehension is hampered by serious difficulties. The biggest of these is that, with psychological experiments being impossible, we cannot hope to obtain certain knowledge of causes and effects where mental processes are concerned. But what the cognitive approach legitimately can do is to use present-day knowledge of discourse comprehension as a heuristic which enables us to recognize the potential explanatory power of the occurrence of linguistic phenomena which other approaches either fail to appreciate or whose occurrence is taken for granted (as in the case of the religious passages inserted in Puritan wills). 


\subsection{Historical background}

What are the general aspects of willmaking in the 16th century? The last will is a genre which was widely familiar and closely connected with everyday life. Model wills, ${ }^{3}$ sermons and the appointment as a testamentary witness were means by which knowledge of the genre and its functions was spread. ${ }^{4}$ In addition, the street and, from the last quarter of the century onwards, the stage function as further sources of information. ${ }^{5}$ Probably the most important factor of all was the Church which, as guardian of a dying man's last words, expected a will with only few exceptions to be forthcoming from everybody. It is estimated that in the 16 th century, up to $10 \%$ of the adult population did make a will. This may appear as a relatively small percentage. But even taking further into account that a number of these wills were never submitted to the ecclesiastical courts for official grant of probate (and thereby risked getting lost in the course of time), ${ }^{6}$ that still leaves hundreds of thousands of these written utility texts in archives ready to be exploited as linguistic source material of nearly all social groups.

A will was usually made on the deathbed. There it offered to people the last if not the only chance for expressing in a permanent medium one's views on death and salvation as one immediately concerned. It is here that the essentially twofold function of the last will as a legal and as a religious instrument becomes evident. In the context of dying, so we may assume, a testator was serious in what he had to say, for he acted on God's explicit command "put thine house in order." by means of a testament, i. e., verbally, can only be successfully achieved if the will is understood by others. Any misinterpretation of the will's terms by the executor carries the risk of serious consequences for the surviving dependants. Here, the particular pragmatic status of this texttype becomes a relevant issue: A last will represents a verbal act with delayed and with delegated performance. Because it may be revoked subsequently to signing, it does only become legally effective as a last will after the testator's death, and then it is submitted for probate, interpreted and executed by the executor as the persona of the testator. Therefore, when the act of bequeathing is finally performed, there is no chance for explanatory comments by the testator himself anymore. This fact makes the executor and his ability to comprehend written discourse most important factors of the pragmatics of last wills.

But with the will being a legal text formal defects, too, apart from misinterpretations and incomprehensibility, can have negative conse- 
quences for the surviving dependants and for the weal of the testator's soul if they forestall the execution of the goods and alms bequests. Presumably for this reason the intended universality of the will led to the cognitively relevant legal provision of minimalized formal requirements, making the will an "exceedingly formless instrument" (Pollock - Maitland 1952, II: 319). The individual testator was in principle free to adapt both language and structure of the will to his private ideas of comprehensibility: "Wordes and sentences are not required for the forme of a testament", as the Elizabethan lawyer Henry Swinburne (1590: f. 190v) put it.

Paradoxically it was this desire of the testator for ready comprehensibility of his will that favoured the strategy of following a well-tried text structure and using traditional formulae. Substantial changes like those made by Puritan testators do therefore deserve our special attention. For the changes to stand out more clearly I shall first briefly describe the most characteristic linguistic property of the non-Puritan, traditional will.

\section{Analysis}

\subsection{The traditional will}

In the traditional will, explicitly religious passages are rare outside its religious preamble. In the preamble, the testator declares that he is making his will in the name of God and the holy company in heaven, that he is of sound mind thanks to God and that he commends his soul to God and his body to the sacred ground in the hope of salvation. This short religious passage is made shorter still and marked as irrelevant for executorial purposes by substituting "etc." for parts of it in the courtcopy which was given to the executor. Those religiously motivated passages that remain - the bequest of the soul and the body, the mortuary, and gifts for prayers for the testator's soul - have the same simple and expedient itemstructure as the worldly bequests of goods and chattels:

First I bequeth my soule to almighty God my maker etc. And my body tobe buried in christione buriell ... Item I bequeth to the fryers obseruantes of Estgreynwyche in countie Kent to pray for my soule $\mathrm{xl}^{\mathrm{s}}$... Item I bequeth to Elizabeth Bac my god daughter to pray for my soule $\mathrm{xl}^{\mathrm{s}}$. Item I bequeth to Sir petir de Lira iiili in bookes. (John Boiedens, University stationer, 1502. Wills II: f. $\left.3^{\mathrm{v}}-4^{\mathrm{r}}\right)^{8}$

The sequential arrangement of items turns out to be the dominating structural principle of the traditional will, which thus subordinates lin- 
guistically the religious function to its legal function. The application of this principle therefore accounts for the traditional will's essentially simple formal superstructure. Except for the preamble's introductory declaration which identifies the testator and states his legal authority ("being of sound mind") as well as the time and the place of making the will, and also excepting the final attestation that the words are the testator's, the will's superstructure does only contain the single functional category of "bequest".

The cognitive relevance of this structure for the recipient and the typical situation of communication in which he makes use of the will is revealed by its essentially list-type character. If we follow Ong (1982: 40) and Goody (1977: 17, 53, $80 \mathrm{ff}$.), lists are a child of literacy because of their demands of the limited human memory capacity. Therefore the contents of lists are processed easier by reading them than by listening to them. For, principally, only a reader is in a position to re-read at will what is still unclear to him or what he has forgotten.

The dominance of the simple list-structure in wills is therefore explained by the lack of any need to make the will's contents memorable. This makes superfluous additional linguistic means such as mnemonic aids. The sequence of itemized bequests follows no principle of cognitive structuring: The bequests are ordered neither according to their nature, nor according to their value, nor according to the degree of relationship of the legatees. Instead, the structure of the traditional will is determined solely by the specific task of the executor, thus complying with his particular demands on comprehensibility as a reader of the last will.

\subsection{The Puritan will}

Let us now turn to the Puritan will. What are the inserted passages in detail? Consistently recurring textual elements are (1) the profession of faith:

I beleeve in god the father, god the sone, and god the holie ghost three persons but one eternall and ever-lyyyng god and I do fullie looke to be saved by thys my beleiff (Thomas Merburie, fellow-commoner, 1571. Wills II: f. 62'),

(2) the confession of having been a sinner:

the damnable pyt of Idolatry wherin I was plonged ... I was most vnworthie yea which well deserved to have been 10000 tymes vtterly reiected from him ... all my stynkynge synnes (Robert Beaumont, 1567, Master of Trinity, Vice-Chancellor, Wills II: f. 45'), 
(3) theological catechizing:

everye man is of thees two partes soule and bodye the soulle being from heaven hevenly/the bodie made of the earthe and is earthlie (Thomas Merburie 1571. Wills II: f. $\left.62^{v}\right)$,

(4) bible quotations:

When I shall heare that Joyfull voyce/come the blessed of my father inherite yee the kyngdome prepared for yow before the begynnynge of the worlde ... according to that saying of the profet David what man is he that lyveth and shall not see deathe ... there is nothyng more vncertayne than the vncertayn howr of deathe, for whoes cause we are admonished in the 24 of matthew continuallie to watche. (Thomas Merburie 1571. Wills II: f. 62 $-63^{r}$ )

and (5) polemical controversy:

withowt all vayne opinion of any mans merites which I do vtterly reiecte, deteste and abhorre as mervellous Iniurious to the blude of my savior Jesus ... (Thomas Merburie 1571. Wills II: f. 62v).

The effect of passages such as these on the comprehension of the will by the executor is briefly stated. The mixing of burial instructions and alms bequests with religious considerations increases the processing load of the executor by forcing him frequently to decide between what is relevant and what is irrelevant for his task. In the will of Robert Beaumont, the relevant instruction concerning the burial is embedded in religious utterances which are superfluous for executing the instruction:

And for my body I desyer that it may be buried semely in the churche Chappell or churcheyarde where I departe and leave from this sinfull lyffe Provyded that my buryall nor after there be no vayne Jangelynge of belles nor anye other popishe ceremonyes or mystrustfull prayers as though my happye state with God were doubtefull. (Robert Beaumont 1567. Wills II: f. $45^{r}-45^{v}$ )

In order to understand what the relevant instruction is, the executor, after semantically decoding this passage, first has to recognize that the contents of "and leave from this sinfull lyffe"; "vayne"; "mystrustfull"; and "as though my happye state with God were doubtefull" do not represent anything which he can "execute", and then he has to process them further, i.e., delete them mentally. In the following extract from the will of Henry Cockrofte, the clause "wherof it cam" and the whole passage extending from "vntyll" to "attayne vnto" are irrelevant for the task of arranging the burial:

My bodye also I do commende vnto the earth wherof it cam there for to rest in Christen mans buriell vntyll the seconde commynge of our savior Christe when bothe bodye and soolle shalbe ioyned togyther agayne and receave that heavenly 
blysse and Joye which we all most certaynelye loke for to attayne vnto. (Henry Cockcrofte 1566. Wills II: f. $46^{v}$ )

Instead of complying with the particular comprehensional situation of the executor, the religious textelements make it more difficult for him to identify that part of the information which is both stimulus and matter for his activity.

On the other hand, these very insertions of professions of faith, bits of theological thinking and polemical rejections of ceremonies and tenets fulfill the functions of persuading, asserting and attacking which ask for the public in order to achieve a maximum effect. The profession of faith and publicity, for instance, are explicitly correlated with each other:

\footnotetext{
"Yt shalbe evident to all that duryng my lieffe I held the profession and beleiff of a trew Christian man ... And herin doe I openlie deteste the fond opinion of the papistes" (Thomas Merburie 1571. Wills II: f. $62^{\mathrm{v}}$ ).
}

Whom does this "all" represent? What kind of audience are we to regard as the public in the case of testaments? Considering the fact alone that a valid last will usually exists or is available for the executor in a single manuscript copy only, it would have to be a listening audience. (In Cambridge, after 1540 the Vice-Chancellor's Court generally kept the original and handed out to the executor an official courtcopy.) The following analysis will show how the specific conditions of text comprehension for a public listening audience are met by the linguistic phenomena pertaining to the Puritan changes of the will. In detail these phenomena are: the occurrence of negations, the occurrence of religious binomials and of paraphrases, of phonological and rhythmic structures, and finally the occurrence of elliptic pro-forms as means of inter-sentential coherence, mone of which are typical features of the traditional testament. They will be analysed from the cognitive point of view under the headings of "schema modification", "mnenonic aids" and "semantic coherence".

\subsubsection{Schema modification}

"Schema" in the sense of Graesser (1981: 29-35) refers to an ordered cluster of knowledge which is activated in discourse comprehension as the pre-knowledge of the recipient and which may be modified by the knowledge manifested linguistically in the text. As pre-knowledge, it provides the relevant knowledge frame for comprehending the text. It directs the comprehender's attention, guides his expectations and enables him to bridge gaps in the text by inferencing - gaps, that is, which stand for knowledge presupposed by the speaker/writer as known to the com- 
prehender. The knowledge of text-types and their functions, too, is assumed to be organized in the form of schemata. Schema modification is a relevant issue here because the schema of the texttype last will is changed by the religious parts inserted into Puritan wills while at the same time the traditional label of last will and testament is retained. In this context, the use of negatives, which will be discussed presently, fulfills an essentially comprehension-guiding function.

By integrating religious textual elements of the sort described above the superstructure of the testament is made more complex. Prayers, admonitions, catechizings and confessions represent textual elements which explicitly fulfill functions different from that of a testamentary bequest or instruction: "This I do take to be the sure and perfyt confessyon of my fayght" (John Scarlett, stationer, 1551. Wills I: f. 89'). Therefore, the function of the traditional label last will and testament as schemaactivating cue will generate wrong expectations in an audience whose knowledge of the texttype last will is determined by the traditional, preReformation will. For we must not forget that Puritanism was still an emerging phenomenon; the group-identifying term Puritan itself is not recorded prior to $1566 .{ }^{9}$

Even if comprehension of the changed testament is made easier by the fact that its religious textual elements were familiar from their original context of worship - they represent four of the six ordinances of the radical Protestant worship $-{ }^{10}$ negation still fulfills its part in the strategy of comprehension management by the testator. Its preference over other means of linguistic encoding is strikingly demonstrated by the will of Thomas Fletcher, where "and solely hopinge" is crossed out and substituted by "no thinge waveringe nor doubtinge" in the original manuscript. ${ }^{11}$ The following examples demonstrate the range of expressing negation in the Cambridge wills:

Provyded that at my buryall nor after there be no vayne Jangelynge of belles nor anye other popishe ceremonyes or mystrustfull prayers" (Robert Beaumont 1567. Wills II: f. $45^{\mathrm{v}}$ ),

Fyrst I geve not as a recompens for my negligent dewits but as a playne and sure commaundement of god sett furthe in his holy worde in dyuers places as exodus leviticus and deuteronomium ... to the poore mens boxe (John Scarlett 1551. Wills I: $\left.f .89^{r}\right)$,

My bodie also I commende vnto the earth to be buried ... withowt all pompe veyne glorie or superstitious facion eyther in mournyng apparell or chauntage at my buriall or other wyse not onlie vnprofitable to me but also to the hearer (Thomas Merburie 1571. Wills II: f. $62^{\mathrm{v}}$ ), 
Being assuredly perswaded of my vndowghted salvation by no other meanes but by the onlye deathe and passion of Christ Jesus (William Burwell, vintner and University appraiser, 1587. Wills II: f. 105').

What precisely is the cognitive effect of these occurrences of negation in the context of schema modification?

The explicit quoting of what the testator either does not believe to be true or does not want to be done guides comprehension in that it puts right an anticipated "wrong" expectation of the recipient. In the examples quoted, these are expectations connected with knowledge schemata which are signalled by the terms "burial", "salvation", "rest" and "negligent dewties". They represent ordered and conventionalized sequences of actions or clusters of concepts from the religious domain which the testator presupposes to be known to recipients but which he, being a Puritan, wants to change. Again we must not forget that from the 1560s Puritanism was associated with innovation and subversion (Porter 1970: 5).

The cognitive effects of negations include more than just putting right "wrong" expectations of recipients. The quoting of individual rejected elements facilitates and makes faster the access to the appropriate knowledge frame, to a specific schema or sub-schema. This, too, is valid only under the condition that the negated contents of an utterance represent knowledge which the recipients actually possess. The rejected elements of jangling bells and praying for the soul of the dead in the examples just quoted are fixed and to-be-expected elements of the traditional burial schema. Thus, it is traditional knowledge which is negated by no, by no other means, and not ... but (and, wherever applicable, substituted by "new knowledge") in the wills of Puritan testators who are committed to the idea to bring about a change. The precise locating of single to-bedeleted as well as to-be-substituted knowledge elements in the recipients' relevant schemata is guided by the negation of explicitly or even implicitly ("and by no other means") stated elements. By this means, the new is more easily anchored in the relevant schema and the schema itself is thus successfully modified.

As cognitive effects of linguistic means on the comprehension of the recipient may be a two-sided matter, "trade-off" becomes a relevant issue in evaluating them. We shall therefore also have to consider briefly the unfavorable effects of negations on comprehension processes. From experiments it is known that negative constructions require more time for decoding than assertive constructions - which in itself is a sure sign of an increased processing load. However, in the context of a public reading of a testament for the purposes of edification, catechization and persua- 
sion, the positive effect of facilitating the integration of new knowledge elements is to be rated higher than the unfavorable effect of an increased processing time. Moreover, we shall presently see that there are other linguistic features of Puritan wills which counter the negative effect of an increased processing time.

\subsubsection{Mnemonic aids}

New information is not easy to retain under the conditions of a single, non-repeated presentation. This is a common experience in situations where texts are read out to a listening audience. It is still less easy in the linguistic context of negative constructions just discussed. But among the linguistic phenomena typical of Puritan wills there are also such as have a decidedly positive mnemonic effect. Because of the limited capacity of the human memory these are especially relevant in situations of oral communication which normally do not admit of repetitions at will.

Mnemonic aid is provided by phonological and rhythmic structures known from oral poetry. In the wills of Robert Beaumont and Richard Streat we find: "The damnable pyt of Idolatry ... his glorious gospel ... my stynkynge synnes" (Robert Beaumont 1567. Wills II: f. 45"); "the mercies and merites" (Richard Streat, fellow of Pembroke, 1588. Wills II: f. $110^{r}$ ). These examples point distinctly towards dactylic metre, alliteration and assonance - means which, being phonic and rhythmic, achieve their full mnemonic impact when read aloud to a listening audience. This function of their occurrence in these wills is made more evident still by the fact that they occur with expressions which refer to central religious tenets either new or reinterpreted: the rejection of images within the religious domain, the authority of the Bible, sin and grace.

Apart from these structures, the occurrence of binomials is mnemonically hepful, too, because of the repetitive nature of these parallel expressions. A binomial is a pair or sequence of syntactically coordinated and semantically related, often near-synonymous words of the same formclass. They have a long tradition in legal English (Mellinkoff 1963: $121-122$ ), being obviously intended as a safeguarnd against legal contesting of provisions. Their high frequency makes them a style-marker in law language (Gustafsson 1984: 123). As such they occur in the traditional as well as in the Puritan will, often in combination with multinomials: "I ... do make and ordayne this my last wyll and testament in maner and forme Folowing; hereby revokyng and disanullyng all former wylles and testamentes by me made ... First and principallye I give and bequeath ... 
my lease/right/title/terme and interest." (William Bosome, apothecary, 1582. Wills II: f. $87^{\mathrm{v}}$ ).

Puritan testators significantly transfer the use of binomials to the domain of religious concepts, where the argument of "legal safeguarding" is no longer a convincing explanation for their occurrence: "I most humbely beseche hym so to washe and cleanse me with the bloude of his great and only redeemer" (Robert Beaumont 1567. Wills II: f. 45 ); "trusting throughe ... Jesus Christ my onlie savior and redeemer to have Free pardon and forgyvenesse of all synnes and iniquities" (William Bosome 1582. Wills II: f. $87^{\mathrm{v}}-88^{\mathrm{r}}$ ); "where I hope to have rest by the mercies and merites of my savior Jesus Christ" (Richard Streat 1588. Wills II: f 110 ); "no thinge waverynge nor doubtinge" (Thomas Fletcher 1582); "I beleeve most steadfastlie to obtayne free forgyuenes and remission of by synnes ... duryng my lieffe I held the profession and beleiff of a trew Christian

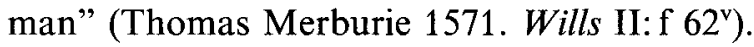

Emphasizing the concepts of forgiveness, of the certainly of salvation, of justification, of grace and of the savior by formulaic combinations of synonymous terms makes these hotly debated issues more memorable for a listener. Moreover, the fact that the pairs of terms do not strictly represent cases of repetition but of paraphrase lends them a further property. They are alternatives offered to a heterogeneous audience of recipients whith different lexical knowledge. As pairs of lexemes of different etymological origins, profession-belief, savior-redeemer and forgiveness-remission, to name but a few, function as mutually explaining translations of each other.

A repetition-induced mnemonic effect on the sentence-level is offered by the Puritan "thanks-and-praise" formula which precedes the bequests of worldly possessions: "Concerninge my earthly goodes wherwith God hath blessed mee I giue all to ..." (William Fulke, Master of Pembroke, 1589. Wills I: f. $112^{\mathrm{r}}$ ); similarly: "desirous to have in Redines my last disposition concerninge the worldlye goodes wherwith yt hathe pleased god to endewe me ..." (Thomas Hoddilowe, brewer, 1595. Wills II:f. $135^{\mathrm{r}}$ ). It takes up the similar thanks-and-praise-formula for being of sound mind, which is common in the religious preamble of both traditional and Puritan testaments: "I Oswalde Archar of Clare hall in Cambryge of hole mynde and in good and perfyte remembraunce lawde and prayse be vnto Allmygthye god" (Oswald Archar, butler, master's servant, Clare, 1547. Wills I: f. $80^{\mathrm{r}}$ ). Thanksgiving and praise, too, are concepts emphasized by the Puritans, especially when it is a matter of expressing gratitude and praise towards God for property acquired through one's 
calling in life. ${ }^{12}$ It renders this property a visible sign of God's grace shown to the individual testator, who thereby proves himself to belong to His elect. Puritans therefore had a strong interest in the lasting dissemination of these concepts in the minds of people. Their partial recurrence in the formula for wordly possessions thus becomes a cognitively relevant mnemonic means in Puritan wills.

A further linguistic phenomenon typical of the Puritan changes of the traditional will is the use of proforms. They are discussed here under the heading of "mnemonic aids" because of their implications for memory, remembering and the retention of verbal material, being elliptic forms which serve as a means of syntactic cohesion. In the sentence "now this I do take to be the sure and perfyt confessyon of my fayght" (John Scarlett 1551 . Wills I: f. $89^{\mathrm{r}}$ ), this refers anaphorically to the contents of the confession of faith expressed earlier in the will: "whome he hathe redemyd by his only deathe and passyon" (and which itself contains proforms referring back to the testator "John Scarlett" and to "God" respectively). The elliptic this requires far less processing time than the clause it stands for, and it enables the comprehender to keep the clause's "access point" to its contents in his limited working memory in order to establish coherence with the proposition processed after it (cf. van Dijk 1980a: 165). Because of its reduced processing time and its storage-saving shortness, the elliptic proform this has a beneficial processing effect especially on listeners who have no means of rereading the text and who don't have to execute a sequence of instructions item by item, but instead are expected to follow a train of connected religious discourse or reasoning.

Traditional wills (and the legal parts of Puritan wills) tend to avoid proforms as a means of inter-sentential cohesion and instead repeat proper names, genre names and other full lexical expressions:

\footnotetext{
My wretched body tobe buried in the southe yle in the churche of oure Lady beside the markett in Camebrige. Item I bequeth to the hye awtere in the sayd churche of oure Lady ... Item I wille that imediatly aftere the southe yle of the said churche of oure Lady is new made ... Item I gyff and bequeath to John Veyse my sonne alle my londes and tenementes ... the sayd John Veysee to have and to hold the sayd londes and tenementes ... Item yff it fortune the sayd John Veesey to discease withoute heyers ... (Henry Veesy, apothecary, 1503. Wills I: f. $4^{\mathrm{v}}-6^{\mathrm{r}}$ )
}

Here, twice the sayd churche is repeated where syntax, in the first instance, would have allowed its substitution by the shorter there, and in the second by it. Similarly, the name of the beneficiary of the testator's lands and tenements, John Veesy, is repeated in full in two successive bequests after 
its first occurrence instead of being substituted by the elliptic pronouns he and him.

The executor as reader of a legal instrument does not profit by the use of proforms as a listener does. On the contrary, proforms make the execution of his task more difficult because they principally reduce the degree of a text's determination, making it semantically less unambiguous than a full repetition of expressions, of proper names and generic terms does. Because proforms cannot be interpreted without the coreferent expression which they substitute, an executor trying to comprehend a specific instruction would have to turn to an earlier instruction as well, whereas the repetition of expressions reduces that necessity. Repetition supports full determination and unambiguity of single instructions: by repeating the full name of John Veesy, it is clear in each of the three bequests independently of the other two who the beneficiary is. The testator's strong interest in legal safeguarding meets the specific recipient's interest of guided comprehension. Repetition avoids the risk that, from a purely syntactic point of view, the occurrence of a proform may refer to more than one expression in a given preceding context. The avoidance of proforms therefore is a typical feature of legal language which aims at full linguistic determination to minimize the chances of legal contestation of its terms.

This fact that proforms, being weakly determined forms, cannot always be matched unambiguously with only one - the appropriate - substituted full expression increases the amount of processing work. This may be further increased by a representational problem when it is a question of "which of several syntactically possible expressions or phrases is the one substituted or represented by the form this?" Even if syntactically there is no problem in identifying the coreferent expression, a long interval between an expression and its proform may still present the mnemonic and representational difficulty of remembering it, necessitating timeconsuming search strategies.

These negative implications of the use of proforms principally hold for any comprehender. Does this not contradict our claim to interpret the occurrence of proforms in Puritan wills in terms of comprehension guiding? Here again the concept of trade-off is the answer. Gains and losses with regard to comprehension management by a particular linguistic phenomenon have to be weighed differently, dependent on the situation of communication and the specific needs of a given comprehender. For a listener who (as one to be edified) is a spiritual beneficiary of the will only, there is less need of full linguistic determination (= avoidance of 
proforms) and legal safeguarding than there is need of a reduced processing load ( = use of elliptic proforms). For this recipient, any loss in determination is more than made up for by the gain in processing time on account of elliptic proforms which enables him to follow the speed of reading aloud more closely. Similarly, any possible loss from the occurrence of proforms (forgetting the substituted coreferent expression or having difficulty in identifying the appropriate one of several potentially coreferent terms) weighs less heavy for him who doesn't have to fear legal consequences from misinterpretations than the just described gain of an easier adaption to the speed of reading aloud and of an easier connecting of new propositions to old ones.

On the other hand, for the executor as reader, this gain does not count much because he may re-read prior propositions at will. Instead, for him the gain in determination and disambiguation of the testator's instructions brought about by repetition (= avoidance of proforms) outweighs any gain in processing speed by elliptic proforms.

Finally, the load for the listener of having to remember the substituted expression to be able to interpret its proform is mitigated by other linguistic features of Puritan wills - the mnemonic aids discussed earlier, including the paraphrases by synonymous terms. These do not help the executor to perform his legal function, because "synonyms" are open to contestation. The occurrence of proforms therefore is evidence for the guided, specific nature of the comprehension management in Puritan wills.

\subsubsection{Semantic coherence}

The analysis of the propositional content of the property-related thanksand-praise-formula and its hierarchical rank within the overall propositional structure of the Puritan will discloses a further instance of comprehension management. Its cognitive effect rests on the fact that the underlying proposition of this formula contributes to the semantic coherence of the will as a whole. The construction of semantic coherence is part of the recipient's interaction with the text and as such it is part of the comprehension process.

Here, the occurrence of the thanks-and-praise-proposition enables the recipient to establish an explicit connection between the religious part of the testament and the individual wordly bequests: "My body I comitt vnto the earth from whence it was taken in stedfaste hope of a glorious resurrection vnto lyfe euerlastinge through the mercy and merittes of the 
same our Lord Jesus Christe. Concerninge my earthly goodes wherwith God hath blessed mee I giue all to ..." (William Fulke 1589. Wills II:f. $112^{r}$ ). The reference to the linguistic centre God sets forth a semantic property which both parts of the testament have in common and which therefore enables the comprehender to construct the global semantic coherence of the will.

Moreover, the scope of this proposition extends over all those propositions which have, as one of their arguments, the concept of a particular piece of goods and chattels, of a fixed sum of money, or of a building or piece of land. These individual legacies can be described by bundles of semantic features: in the case of household goods, for instance, these would be $\langle+$ concrete $\rangle,\langle-$ animate $\rangle,\langle+$ movable $\rangle$ and so forth down to the feature finally distinguishing one piece of chattel from another. The explicitly stated additional, religious quality of <grace, coming from God > contained in the thanks-and-praise formula for property signals a semantic feature common to the individual, disparate household items. Their full comprehension is dependent on the comprehension of the first, widescope proposition. This helps the comprehender to keep mentally together the disparate item bequeathed by the testator in the Puritan sense of a visible sign of divine election. The thanks-and-praise proposition concerning wordly goods thus makes the whole of the will's text a confession of faith and makes it also easier to comprehend it as such.

The work of van Dijk (1980b: $46-50)$ has convincingly demonstrated the explanatory power of the concept of "macrostructures" and "macrorules". By applying macrorules such as "generalisation", comprehenders actively construct global macropropositions of their own whose scope covers the predicates of the hierarchically lower local micropropositions. This operation ensures the comprehension of the gist of a text's message, whose local propositions cannot be kept individually in memory. The thanks-and-praise formula expressing explicitly a macroproposition therefore is evidence of a guided formation of macropropositions and hence, comprehension management. Moreover, it is audience-specific, for this particular macroproposition does not help the executor's goal-directed comprehension of the will's instructions. On the contrary, the executor benefits from the lack of any such proposition in the traditional will which leaves unblurred the semantic-pragmatic distinction between the religious bequests of the soul and the body on the one hand the wordly bequests of goods and rights on the other as in the following example:

First I bequeth my soule to almighty God my maker etc. Item I will that my body be buried in christione buriell wher it shall please God for me to dispose. Item I 
bequeth to the fryers obseruantes of Estgreynwyche in countie of Kent to pray for my soule $\mathrm{xl}^{\mathrm{s}}$. Item I bequeth to Elizabeth Bac my god daughter to pray for my soule $\mathrm{xl}^{\mathrm{s}}$. Item $\mathrm{I}$ bequeth to Sir petir de Lira iiili in bookes. (John Boiedens 1502. Wills I: f. $\left.3^{v}-4^{\mathrm{r}}\right)$

Here, the material bequests of money and books are not semantically bound to the religious bequests of the soul and the body by any formula which lends to property the religious status of a divine grace. This "break" is important because the bequests of the soul and the body cannot be handed over or claimed in court in any sense comparable to that of the worldly legacies.

\section{Conclusion}

Considering all arguments, we are now in a position to answer the initial question of whose comprehension benefits from the Puritan change of the traditional will. The cognitively relevant properties of the linguistic phenomena analysed here, which concern the religious additions typical of the Puritan testament, help the comprehension of the will by recipients who are not its executors (i. e., its readers), but who are a public listening audience. This finding supports the thesis that the audience of a testamentary reading was to be edified, strengthened and catechized in the Puritan belief by having a convincing example of the testator's certainty of faith in the face of death publicly read to them at his burial.

This explanation of the Puritan change of the testament has two more general consequences:

First, the cognitive approach has proved to be a heuristically useful means to recognize the explanatory potential of linguistic phenomena which are either overlooked or taken for granted by other approaches.

Second, the application of this approach has revealed the basic change of the texttype of last will and testament. By its new, additional function the private last will became the single individual's contribution to the spreading and testifying of the new belief and even to the polemic fighting of rejected tenets, thereby ranging alongside the well-tried public texts of Puritan propaganda: sermons, petitions, admonitions, tracts and pamphlets. 
Notes

1. See e.g., William Perkins, A salve for a sicke man. Cambridge 1595; Thomas Becon, The Sycke Mans Salue, London 1561; and Christopher Sutton, Disce Mori. Learne to Die. London 1601.

2. In all matters of religious behavior, the Puritan had four infallible tests, resting on the authority of the Pauline Epistles (I Corinthians 10: 32, 14: 40, 14: 26 and Romans 14: $6-7)$, which provided the criteria of "avoidance of offence"; "order and comeliness"; "edifying"; and "the glory of God" (cf. Davies 1970: 52).

3. See the checklist of fictitious and literary wills including model wills (Bach 1982).

4. The texts of John 14: 27, and Luke 23: 46 contain Christ's bequests of his peace, his mother and his soul; this invites references to the last will and testament in preaching. Cf. John Donne's Sermon preached upon Whitsunday (1630) as a (later) example.

5. Mock wills were published as broadsides and pamphlets and occurred in Elizabethan plays. See Bach (1982), (1977).

6. Until 1750 it was not obligatory to prove a will unless it was disputed.

7. Cf. II Kings 20: 1 "Put thine house in order: for thou shalt die, and not live"; cf. also Isaiah 38: 1 .

8. Except where indicated otherwise, all quotations are from wills proved at the ViceChancellor's Court of the University of Cambridge and registered in two volumes of manuscript court-copies: Wills I (1501-1558), Wills II (1558-1602), which are kept in the University Archives.

9. OED, s. v. "Puritan".

10. The six ordinances are Prayer, Praise the proclamation of the Word, the administration of the Sacraments, Catechising, and the exercise of Discipline (Davies 1970: 70). Of these, Prayer is represented by the inclusion of the confession of faith. Praise by the formula expressing gratitude for sound mind and for worldly goods, the proclamation of the Word by the bible quotations, and Catechising by the passages containing theological lore.

11. Thomas Fletcher of Barking, Essex, 1582 (Essex County Record Office, Chelmsford).

12. This is commonly known by the concept of "lively faith". Cf. Davies (1970: 20).

\section{References}

Bach, Ulrich

1977

1982 Kommentierte Bibliographie englischer literarischer Testamente. (Anglistische Forschungen 163). Heidelberg: Carl Winter Universitätsverlag.

Danet, Brenda 1985

Davies, Horton

1970

"Legal discourse", in: Teun A. van Dijk (ed.), 273-291.

Worship and theology in England: From Cranmer to Hooker 1534-1603. Princeton University Press. 
Dijk, Teun A. van

1980a

$1980 \mathrm{~b}$

- (ed.)

1985

Textwissenschaft: Eine interdisziplinäre Einführung. Tübingen: Niemeyer.

Macrostructures. An interdisciplinary study of global structures in discourse, interaction, and cognition. Hillsdale, NJ: Lawrence Erlbaum.

Handbook of discourse analysis. Vol. 1 Disciplines of discourse. London: Academic Press.

Di Pietro, Robert J. (ed.)

1982 Proceedings of the second annual Delaware Symposium on language studies. (Advances in Discourse Processes, VIII) Norwood, NJ: Ablex.

Finegan, Edward

1982 "Form and function in testament language", in: R. J. Di Pietro (ed.), $113-120$.

Fisher, Sue - Alexandra D. Todd (eds.)

1986 Discourse and institutional authority: Medicine, education, and law. (Advances in Discourse Processes XIX). Norwood, NJ: Ablex.

Goody, Jack

1977

The domestication of the savage mind. Cambridge: Cambridge University Press.

Xraesser, Arthur C.

1981 Prose comprehension beyond the word. New York-Heidelberg-Berlin:

Gustafsson, Marita Springer.

1984 "The syntactic features of binomial expressions in legal English", Text 4: $123-141$.

Heal, Felicity - Rosemary O'Day (eds.)

1977 Church and society in England: Henry VIII to James I. London: Longman.

Kurzon, Dennis

1984 "Themes, hyperthemes and the discourse structure of British legal texts", Text 4: 31-55.

1986 It is hereby performed .... Explorations in legal speech acts. (Pragmatics and Beyond VII: 6) Amsterdam: John Benjamins.

Mellinkoff, David

1963 The language of the law. Boston-Toronto: Little, Brown.

Ong, Walter J.

1982 Orality and literacy: The technologizing of the word. London: Methuen.

Pollock, Frederic - F. W. Maitland

1952 The history of English law before the time of Elizabeth I. Vol. 2. Cambridge:

Cambridge University Press.

Porter, Harry C.

$1970 \quad$ Puritanism in Tudor England. London: Macmillan.

1958 Reformation and reaction in Tudor Cambridge. Cambridge: Cambridge University Press.

[1972] [reprinted Hamden, Conn.: Archon Books]

Schlieben-Lange, Brigitte

1983 Traditionen des Sprechens: Elemente einer pragmatischen Sprachgeschichtsschreibung. Stuttgart-Berlin-Köln-Mainz: Kohlhammer. 
Spufford, Margaret

Contrasting Communities: English villagers in the sixteenth and seventeenth centuries. Cambridge: Cambridge University Press.

Texts

Becon, Thomas

1561

The Sycke Mans Salue. Wherin the faithfull Christians may learne both how to behaue themselues paciently and thankefully in the tyme of sickenes, and also vertuously to dispose their temporall goodes ... London.

Donne, John

[1953-62] The Sermons of John Donne, E. M. Simpson-G. R. Potter (eds.) 10 vols. Berkeley: University of California Press

Perkins, William

1595

A salve for a sicke man, or, A treatise containing the nature, differences, and kindes of death, as also the right manner of dying well ... Cambridge.

Sutton, Christopher

Diese Mori. Learne to Die. A Religious Discourse, moouing euery Christian Swinburne, Henry man to enter into a serious remembraunce of his ende ... London.

A briefe Treatise of Testaments and last Willes ... London: John Windet.

\section{Manuscript Sources}

Probate records of the Vice-Chancellor's Court. University Archives, Cambridge (Wills I-II, 1501 - 1602). Probate records. Essex Country Record Office. Chelmsford. 